\title{
Brazilian Amazon Traditional Medicine and the Treatment of Difficult to Heal Leishmaniasis Wounds with Copaifera
}

\author{
Kelly Cristina Oliveira de Albuquerque, ${ }^{1}$ Andreza do Socorro Silva da Veiga, \\ João Victor da Silva e Silva, ${ }^{1}$ Heliton Patrick Cordovil Brigido, ${ }^{1}$ \\ Erica Patrícia dos Reis Ferreira, ${ }^{1}$ Erica Vanessa Souza Costa, ${ }^{1}$ \\ Andrey Moacir do Rosário Marinho, ${ }^{3}$ Sandro Percário, ${ }^{4}$ and Maria Fâni Dolabela ${ }^{1,2}$ \\ ${ }^{1}$ Programa de Pós-Graduação em Ciências Farmacêuticas, Instituto de Ciências da Saúde, \\ Universidade Federal do Pará, Belém, PA, Brazil \\ ${ }^{2}$ Programa de Pós-Graduação em Inovação Farmacêutica, Instituto de Ciências da Saúde, \\ Universidade Federal do Pará, Belém, PA, Brazil \\ ${ }^{3}$ Faculdade de Química, Instituto de Ciências Exatas e Naturais, Universidade Federal do Pará, Belém, PA, Brazil \\ ${ }^{4}$ Laboratório de Estresse Oxidativo, Instituto de Ciências Biológicas, Universidade Federal do Pará, Belém, PA, Brazil
}

Correspondence should be addressed to Maria Fâni Dolabela; fanidolabela20@gmail.com

Received 13 August 2016; Accepted 25 October 2016; Published 17 January 2017

Academic Editor: Chiranjib Pal

\begin{abstract}
Copyright (C) 2017 Kelly Cristina Oliveira de Albuquerque et al. This is an open access article distributed under the Creative Commons Attribution License, which permits unrestricted use, distribution, and reproduction in any medium, provided the original work is properly cited.
\end{abstract}

\begin{abstract}
The present study describes the use of the traditional species Copaifera for treating wounds, such as ulcers scarring and antileishmanial wounds. It also relates phytochemical studies, evaluation of the leishmanicidal activity, and toxicity. The species of Copaifera with a higher incidence in the Amazon region are Copaifera officinalis, Copaifera reticulata, Copaifera multijuga Hayne. The copaiba oil is used in the Amazon's traditional medicine, especially as anti-inflammatory ingredient, in ulcers healing, and in scarring and for leishmaniasis. Chemical studies have shown that these oils contain diterpenes and sesquiterpenes. The copaiba oil and terpenes isolated have antiparasitic activity, more promising in the amastigote form of L. amazonensis. This activity is probably related to changes in the cell membrane and mitochondria. The oil showed low cytotoxicity and genotoxicity. Furthermore, it may interfere with immune response to infection and also has a healing effect. In summary, the copaiba oil is promising as leishmanicidal agent.
\end{abstract}

\section{Introduction}

In history, many civilizations have left traces of their culture on objects; moreover there were also expressed diseases that affected them. Skin lesions and human facial deformities were depicted in ceramics of Peru and Ecuador's pre-Inca civilizations; these ceramics are dated from the beginning of 1st century B.C. In the 15th and 16th centuries, texts found in the Americas mention the risk of getting the "diseases of the Andes"; these diseases afflict agricultural workers and are characterized by very debilitating injuries $[1,2]$.

In Brazil, the document of the Geographic Political Religious Pastoral (1827) is considered the first report of leishmaniasis in the country. This work recounts the journey of
Don Frei Hipólito Sanches Fayas and Quiros Tabatinga (AM) by the Brazilian Amazon to Peru [3]. Moreira (1895) was the first to identify cases of leishmania in Brazil; this period was known as "Bahia's button" or "Biskra's Button." Gaspar Viana (1911) identified the parasite involved in the pathology and named it as Leishmania braziliensis [4]. Aragon (1922) demonstrated the role of the sandfly in the transmission of cutaneous leishmaniasis. Since then, the transmission of the disease has been described in several cities of all federal units (UF) [5]. The cutaneous form is characterized by the presence of a difficult to heal "ulcer" [6].

Over the centuries, products of plant origin were the basis for treatment of various diseases. Phytochemical studies of some species led to the isolation of many drugs [7]. In 
TABLE 1: Terpenes present in Copaifera.

\begin{tabular}{|c|c|c|}
\hline \multirow{2}{*}{ Sesquiterpenes } & \multicolumn{2}{|l|}{ Diterpenes } \\
\hline & Clerodanes & Labdanes \\
\hline $\begin{array}{l}\text { Alloaromadendrene, ar-curcumene, } \\
\alpha \text {-bergamotene, } \beta \text {-bergamotene, } \\
\text { ar-curcumene, bicyclogermacrene, } \\
\beta \text {-bisabolene, } \beta \text {-bisabolol, cadalene, cadinene, } \\
\alpha \text {-cadinene, } \delta \text {-cadinene, } \gamma \text {-cadinene, } \alpha \text {-cadinol, } \\
\text { calamenene, caryophyllene, } \beta \text {-caryophyllene, } \\
\alpha \text {-caryophyllenol, cedrol, } \alpha \text {-cedrene, cyperene, } \\
\text { copaene, } \alpha \text {-copaene, } \beta \text {-copaene, } \gamma \text {-elemene, } \\
\beta \text {-farnesene, trans- } \beta \text {-farnesene, germacrene B, } \\
\text { germacrene } \mathrm{D}, \alpha \text {-guaiene, } \beta \text {-guaiene, } \\
\text { y-guaiene, guaiol, humulene, } \alpha \text {-humulene, } \\
\beta \text {-humulene, } \gamma \text {-humulene, ledol, longiciyclene, } \\
\alpha \text {-multijugenol, t-muurolol, } \alpha \text {-muurolene, } \\
\gamma \text {-muurolene, caryophyllene oxide, } \alpha \text {-selinene }\end{array}$ & $\begin{array}{c}\text { 3,13-clerodadiene-15,16-olide-18-oic acid } \\
\text { 3-clerodene-15,18-dioic acid } \\
\text { 13-clerodene-15,16-olide-18-oic acid } \\
\text { 3,13-clerodadiene-15-oic acid } \\
\text { 3,13-clerodadien-15-ol } \\
\text { ent-15,16-epoxy-7 } \beta \text {-hydroxy-3,13(16),14- } \\
\text { clerodatrien-18-oic acid } \\
\text { ent-(19a)-3,13-clerodadien-15-ol } \\
\text { ent-neo-4(18), 13-clerodadien-15-ol } \\
\text { clerodene-15,18-dioic acid } \\
\text { ent-15,16-epoxy-13(16),14-clerodadien-18-oic acid } \\
\text { ent-15,16-epoxy-3,13(16),14-clerodatrien-18-oic acid } \\
\text { (+)-7 } \beta \text {-Acetoxy-15,16-epoxy-3,13(16),14- } \\
\text { clerodatrien-18-oic acid }\end{array}$ & $\begin{array}{l}\text { ent-3-hydroxy-labda-8(17),13-dien- } \\
\text { 15-oic acid } \\
\text { ent-8(17),13-labdadien-15,19-dioic } \\
\text { acid } \\
\text { ent-8(17)-labden-15-oic acid } \\
\text { ent-8(17)-labden-15,18-dioic acid } \\
\text { ent-15,16-epoxy-8(17),13(16),14- } \\
\text { labdatrien-18-oic acid } \\
\text { 18-hydroxy-8(17),13-labdadien-15- } \\
\text { oic acid } \\
\text { 8(17), 13E-labdadien-15-oic acid } \\
\text { (13S)-7-labden-15-oic acid } \\
\text { 33-hydroxy-15,16-dinorlabda-8(17)- } \\
\text { en-13-one } \\
\text { 8(17),13-labdadien-15-ol }\end{array}$ \\
\hline
\end{tabular}

the process of wound healing, their use is not different. Plants or extracts were used in the form of poultices to stop bleeding and promote healing [8]. The vegetable oil was used to promote healing [9] and the antileishmania activity [10].

After an extensive review of the literature, we noted the importance of the species Copaifera in the treatment of wounds and leishmaniasis [18, 19]. Copaifera comprises nearly 72 species [13], mainly by their economic and medicinal importance $[20,21]$.

In the Americas 28 different species were described; in Brazil 16 of these species were identified [13]. The most abundant ones were Copaifera officinalis L. (North Amazonas, Roraima, Colombia, and Venezuela), Copaifera guyanensis Desf. (Guianas), Copaifera reticulata Ducke, Copaifera multijuga Hayne (Amazon), Copaifera confertiflora Benth. (Piauí), Copaifera langsdorffii Desf. (Brazil, Argentina, and Paraguay), Copaifera coriacea Mart. (Bahia) and Copaifera cearensis Huber ex Ducke (Ceará) [22-24].

Copaiba oil is used in the Amazon traditional medicine, especially as an anti-inflammatory ingredient and for wound healing $[13,25,26]$, and its use has been reported since the 16th century. America's settlers reported that the American Indians applied this oil in the navel of newborns and wounds of the warriors after battles. This indigenous use originated from the observation of animals that, when wounded, rubbed themselves on the trunk of the copaiba tree to heal their wounds. [27]. In summary, exposure to copaiba oil accelerated the healing of wounds of different origins. The leishmanicidal activity has also been described [10].

The biological properties of Copaifera spp. have been assigned to the diterpenes and sesquiterpenes [28, 29]. The most common sesquiterpenes were caryophyllene, $\alpha$ copaene, zingiberene, $\beta$-bisabolene, and bergamotene. The main diterpenes were kaurenoic, hardwickiic, kovalenic, polyalthic, and copalic acids. The diterpene was major metabolite of Copaifera. Many phytochemical studies have been conducted with species Copaifera and identified several sesquiterpenes (Figure 1) [28-34] and diterpenes clerodanes
(Figure 2) [35-40], and labdanes (Figure 2) [34, 39-43]. Table 1 lists all substances identified in copaiba oil and the figures show chemical structures of the major constituents.

This study describes the traditional use of different species of Copaifera in the treatment of wounds, such as wound healing and leishmaniasis. It also relates this information to phytochemical studies and evaluation of activity and toxicity.

\section{Copaifera's Traditional Use in the Treatment of Wounds and Leishmaniasis}

The most abundant Copaifera species in the Amazon region are Copaifera officinalis, Copaifera reticulata, and Copaifera multijuga Hayne [24]. Many ethnobotanical studies have been shown.

According to Maciel et al. (2002) [44], it is not always possible to identify the origin of this oil (the species that originated it) or the time and place of collection. The $C$. multijuga oil activity and other species vary with the chemical composition of the oil, and this is influenced by the time and place of harvest $[10,44]$.

Copaifera species are used by the population of Barão de Igarape Miri, state of Para, Brazil, for the treatment of poorly healing wounds [11]. The oils of C. guyanensis, C. multijuga, and C. officinalis (Table 2) should be applied two times a day on the affected part for healing ulcers and wounds [45] but without excess [46]. For skin and wound problems, topical application of the remedy of one part oil for 5-10 part glycerin oil is still indicated [47].

The anti-inflammatory activity has been related to sesquiterpene, in particular $\beta$-bisabolene and $\beta$-caryophyllene. Also, some of the diterpenes from the type of kauranes, clerodanes, and labdanes have been identified in copaiba oil. These can contribute to the anti-inflammatory activity of oil $[13,24,48,49]$.

The study of Pinto (2008) reports the use of Copaifera sp. tea for the treatment of wounds (Table 2). Overall, adverse 


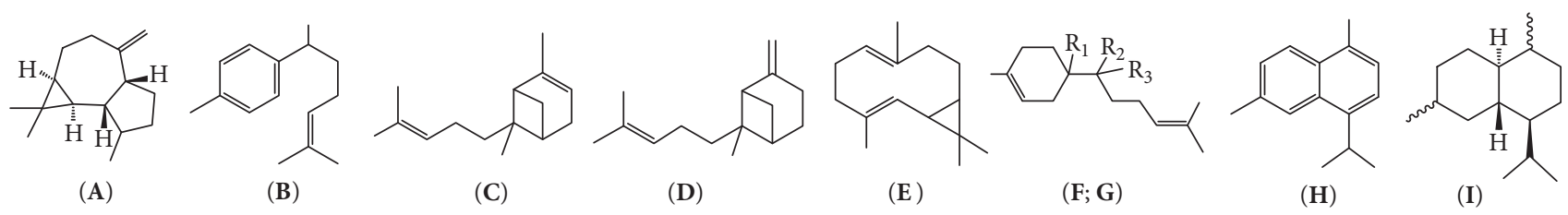

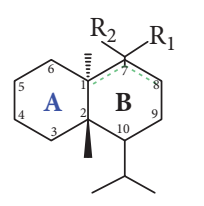

$(\mathrm{J}, \mathbf{K}, \mathbf{L}, \mathbf{M}, \mathbf{N}$, M2, O2, P2)<smiles>[R]C1CCC(C)C2=C(C1)C(C)CC2</smiles>

(A2; B2)

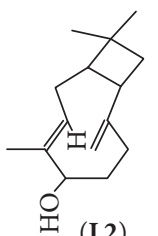

(L2)

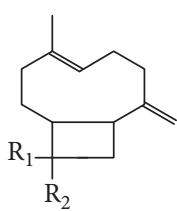

$(\mathbf{O} ; \mathbf{P})$<smiles>[R]C1CCCC(C)CC([R2])CC1</smiles>

(C2; D2; E2)

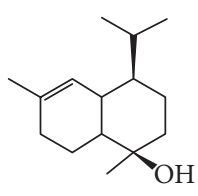

(N2)<smiles>C/C=C\CC/C(C)=C\CC(C)(C)C/C=C\C</smiles>

(Q)

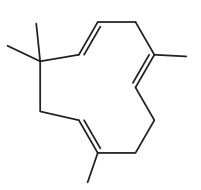

(F2)

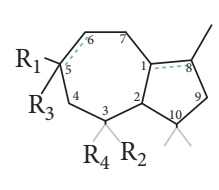

(R; $\mathbf{S}$; T)

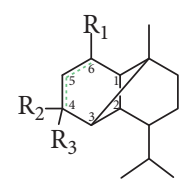

(U; V; X)<smiles>C=CC1(C)CC(=O)C(=C(C)C)CC1C(=C)C</smiles>

(W)<smiles>C=CC(=C)CCC=C(C)CCC=C(C)C</smiles>

(Y)

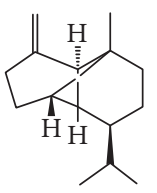

(Z)

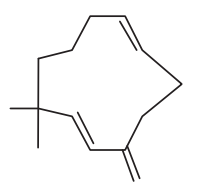

(G2)

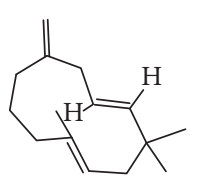

(H2)

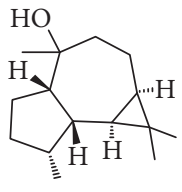

(I2)

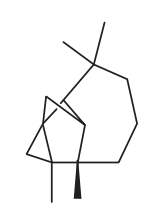

(J2)

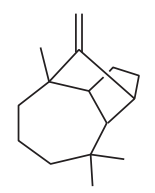

(K2)

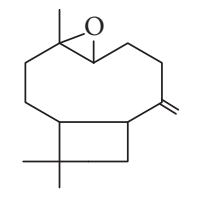

(Q2)<smiles>C=C(C)C1CCC2(C)CCCC(C)C2(C)C1</smiles>

(R2; S2)

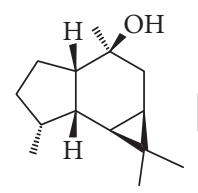

(U2)

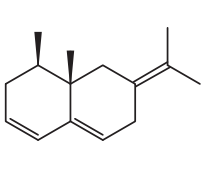

(V2)

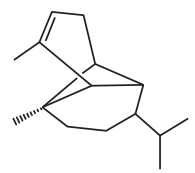

(X2)<smiles>C=CC(=C)CCC=C(C)CCC=C(C)C</smiles>

FIgURE 1: Sesquiterpenes found in copaiba oils. (A) Alloaromadendrene; (B) ar-curcumene; (C) $\alpha$-bergamotene; (D) $\beta$-bergamotene; (E) bicyclogermacrene; (F) $\beta$-bisabolene $\left[\mathrm{R}_{1}=\mathrm{H}, \mathrm{R}_{2}\right.$ and $\left.\mathrm{R}_{3}=\mathrm{CH}_{2}\right] ;(\mathbf{G}) \beta$-bisabolol $\left[\mathrm{R}_{1}=\mathrm{OH}, \mathrm{R}_{2}=\mathrm{CH}_{3}, \mathrm{R}_{3}=\mathrm{H}\right]$; (H) cadalene; (I) cadinene; (J) $\alpha$-cadinene $\left[\mathrm{R}_{1}=\mathrm{CH}_{3} ; \mathrm{R}_{2}=\right.$ not; $\mathrm{C}_{7}=\mathrm{C}_{8} ; \mathrm{A}=4$ - $\mathrm{CH}_{3}$-hexcycl-3-ene $]$; $(\mathrm{K}) \gamma$-cadinene $\left[\mathrm{R}_{1}\right.$ and $\mathrm{R}_{2}=\mathrm{CH}_{2} ; \mathrm{C}_{7}=\mathrm{C}_{8} ; \mathrm{A}=4$ - $\mathrm{CH}_{3}$-hexcycl-3ene]; $(\mathbf{L}) \delta$-cadinene $\left[\mathrm{R}_{1}=\mathrm{CH}_{3} ; \mathrm{R}_{2}=\right.$ not; $\mathrm{C}_{1}=\mathrm{C}_{7} ; \mathrm{A}$ - $\mathrm{CH}_{3}$-hexcycl-3-ene]; $(\mathbf{M}) \alpha$-cadinol $\left[\mathrm{R}_{1}=\mathrm{H} ; \mathrm{R}_{2}=\mathrm{OH} ; \mathrm{A}=4\right.$ - $\mathrm{CH}_{3}$-hexcycl-3-ene]; (N) calamenene $\left[\mathrm{R}_{1}=\mathrm{H} ; \mathrm{R}_{2}=\mathrm{CH}_{3} ; \mathrm{A}=\right.$ benzene]; $(\mathbf{O})$ caryophyllene $\left[\mathrm{R}_{1}=\mathrm{CH}_{3}, \mathrm{R}_{2}=\mathrm{CH}_{3}\right.$, cis $] ;(\mathbf{P}) \beta$-caryophyllene $\left[\mathrm{R}_{1}=\mathrm{CH}_{3} ; \mathrm{R}_{2}=\mathrm{CH}_{3}\right.$, trans]; (Q) $\alpha$-caryophyllenol; (R) cedrol $\left[\mathrm{R}_{1}=\mathrm{H} ; \mathrm{R}_{2}=\mathrm{CH}_{3} ; \mathrm{R}_{3}=\mathrm{OH} ; \mathrm{R}_{4}=\mathrm{CH}_{3} ; \mathrm{C}_{1}, \mathrm{C}_{4}=\mathrm{CH}_{2}\right] ;(\mathbf{S}) \alpha$-cedrene $\left[\mathrm{R}_{1}=\mathrm{CH}_{3} ; \mathrm{R}_{2}=\mathrm{CH}_{3} ; \mathrm{R}_{3}\right.$ $=$ not; $\left.\mathrm{R}_{4}=\mathrm{CH}_{3} ; \mathrm{C}_{1}, \mathrm{C}_{4}=\mathrm{CH}_{2} ; \mathrm{C}_{5}=\mathrm{C}_{6}\right] ;(\mathrm{T})$ cyperene $\left[\mathrm{R}_{1}=\mathrm{H} ; \mathrm{R}_{2}=\mathrm{CH}_{3} ; \mathrm{R}_{3}=\mathrm{H} ; \mathrm{R}_{4}=\mathrm{C}_{2}, \mathrm{C}_{6} \mathrm{CH}_{2}\left(\mathrm{CH}_{3}\right)_{2}\right] ;(\mathrm{U})$ copaene; (V) $\alpha$-copaene; (X) $\beta$-copaene; (W) $\gamma$-elemene; (Y) $\beta$-farnesene; (Z) trans- $\beta$-farnesene; (A2) germacrene $\left.\mathrm{B}^{2} \mathrm{R}_{1}=\mathrm{CH}_{3} ; \mathrm{R}_{2}=\mathrm{C}\left(\mathrm{CH}_{3}\right){ }_{2} ; \mathrm{C}_{6}=\mathrm{C}_{7} ; \mathrm{C}_{2}=\mathrm{C}_{10}\right]$; (B2) germacrene $\mathrm{D}\left[\mathrm{R}_{1}=\mathrm{CH}_{2} ; \mathrm{C}_{4}=\mathrm{C}_{5} ; \mathrm{C}_{9}=\mathrm{C}_{10}\right] ;(\mathrm{C} 2) \alpha$-guaiene $\left[\mathrm{R}_{1}=\mathrm{C}\left(\mathrm{CH}_{2}\right) \mathrm{CH}_{3}\right] ;(\mathrm{D} 2) \beta$-guaiene $\left[\mathrm{R}_{1}=\left(\mathrm{CH}_{3}\right)_{2}\right] ;(\mathbf{E} 2) \gamma$-guaiene $\left[\mathrm{R}_{1}=\right.$ $\mathrm{CH}\left(\mathrm{CH}_{3}\right)_{2} ; \mathrm{C}_{6}=\mathrm{C}_{7}$ ]; (F2) humulene; (G2) $\alpha$-humulene; (H2) $\beta$-humulene; (I2) ledol; (J2) longicyclene; (K2) longifolene; (L2) Longipinene; (M2) $\alpha$-multijugenol $\left[\mathrm{R}_{1}=\mathrm{H} ; \mathrm{R}_{2}=\mathrm{OH} ; \mathrm{A}=4-\mathrm{CH}_{3}\right.$ - hexcycl-3-ene]; (N2) t-muurolol; (O2) a-muurolene $\left[\mathrm{R}_{1}=\mathrm{CH}_{3} ; \mathrm{R}_{2}=\right.$ not; $\mathrm{C}_{7}=\mathrm{C}_{8} ; \mathrm{A}=$ 4-Me-hexcycl-3-ene]; P2: $\gamma$-muurolene $\left[\mathrm{R}_{1}+\mathrm{R}_{2}=\mathrm{CH}_{2} ; \mathrm{A}=4\right.$ - $\mathrm{CH}_{3}$-hexcycl-3-ene]; $\mathrm{Q} 2$ : caryophyllene oxide; $(\mathrm{R} 2) \alpha$-selinene $\left[\mathrm{R}_{1}=\mathrm{H} ; \mathrm{R}_{2}=\right.$ $\mathrm{CH}_{3}$ cis]; (S2) $\beta$-selinene $\left[\mathrm{R}_{1}=\mathrm{H} ; \mathrm{R}_{2}=\mathrm{CH}_{3}\right.$ trans]; (T2) $\beta$-sesquiphellandrene; (U2) viridiflorol; (V2) $\beta$-vetivenene; (X2) $\alpha$-ylangene.

effects of copaiba are dose-related. High doses of the oil can cause gastrointestinal irritation, diarrhea, salivation, and depression of the central nervous system [44]. At a dose of $10 \mathrm{~g}$ shown symptoms of intolerance are nausea, vomiting, cramps, diarrhea, and rash [50].

Some studies evaluating the toxicity of copaiba have already been performed. Pregnant rats were subjected to treatment with copaiba oil $(500,1000$, and $1250 \mathrm{mg} / \mathrm{kg}$ orally), and there was no observed embryotoxicity effect at any dose [51].

The hydroethanol extract of leaves from C. langsdorffii was subjected to evaluation of genotoxicity by the micronucleus test. The mice were treated and genotoxicity was evaluated in acute treatment ( 24 and $48 \mathrm{~h}$ ) and after multiple doses ( 7,15 , and 21 days). This extract was not genotoxic and increased exposure time and dose did not interfere with this toxicity [52]. The ethanol extract obtained from the pulp of the fruit of $C$. langsdorffi presented antioxidant activity and was not genotoxic [53].

Although the extracts and the copaiba oil showed low cytotoxicity, the kaurenoic acid has been demonstrated to be toxic. Continuous exposure of sea urchin embryos (Lytechinus variegatus) to kaurenoic acid, starting immediately after the fertilization, progressively inhibited its development ( $\mathrm{IC}_{50}$ of blastulas: $44.7 \mathrm{mM}$; $\mathrm{IC}_{50}$ of lavae stages: $10 \mathrm{mM}$ ). In the cell viability assay, kaurenoic acid (concentration of $78 \mathrm{mM}$ ) inhibited the growth of leukemic cells (95\%), breast, and colon cancer ( $45 \%$ each). Furthermore, kaurenoic acid induced hemolysis in a dose-dependent manner in rat and 
TABLE 2: Major metabolites of Copaifera used in traditional Amazon medicine.

\begin{tabular}{|c|c|c|c|c|}
\hline Species & Medical use & Part & Major metabolites & References \\
\hline Copaifera sp. & Treatment of injury/wound & Oil; tea & $\begin{array}{l}\text { Copalic acid; kaurenoic acid; } \\
\text { hardwickiic acid }\end{array}$ & $\begin{array}{c}\text { Pinto, } 2008[11] ; \\
\text { Santos et al., } 2008[10]\end{array}$ \\
\hline C. multijuga & Healing & Stalk (decoction) & Copalic acid; hardwickiic acid & $\begin{array}{l}\text { Center of the Workers of the } \\
\text { Amazon (CTA), } 1996 \text { [12]; } \\
\text { Santos et al., 2008 [10] }\end{array}$ \\
\hline C. guyanensis & Healing & Stalk: oil & $\begin{array}{c}\text { Kaur-16-en-19-oic acid; } \\
\text { polyalthic acid; hardwickiic acid }\end{array}$ & $\begin{array}{l}\text { Veiga Jr. and Pinto, } 2002[13] ; \\
\text { Cascon and Gilbert, } 2000[14]\end{array}$ \\
\hline C. officinalis (Jacq.) L. & Healing and leishmaniasis & Stalk: oil & 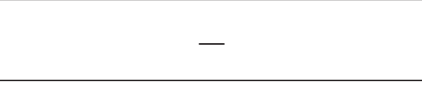 & $\begin{array}{c}\text { Center of the Workers of the } \\
\text { Amazon (CTA), } 1996 \text { [12] }\end{array}$ \\
\hline C. reticulata & Healing & Oil: oil & Copalic acid; kaurenoic acid & Santos et al., 2008 [10] \\
\hline
\end{tabular}<smiles>[R3]CC1(C)C(C)C([R7])CC2([R])C(C(=O)O)=CCCC21C(C)(C)C</smiles>

$(\mathbf{A}),(\mathbf{B}),(\mathrm{C})$,
$(\mathrm{D}),(\mathrm{E})$

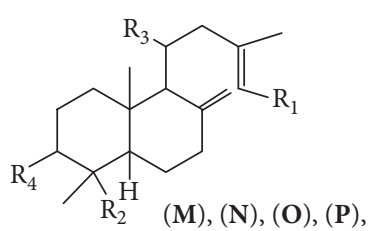

$(\mathbf{Q}),(\mathbf{R}),(\mathbf{S}),(\mathbf{T})$<smiles>[R]C=C(C)CCC1(C)C(C)CCC2(C)C(C)=CCCC21</smiles>

(F), (G), (H)<smiles>C[C@H]1CC[C@H]2C(CC[C@H]3[C@H](C)CCC[C@@]23C)C1C(=O)O</smiles>

(U)<smiles>[R]CC1(C)C(C)CCC2(C)CCCC(C(=O)O)C21</smiles>

$(\mathbf{I}),(\mathbf{J}),(\mathbf{L})$

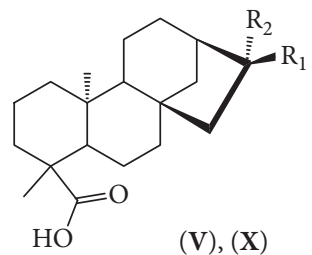

FIGURE 2: Diterpenes found in copaiba oils. (A) Patagonic acid $\left[\mathrm{R}_{1}=\mathrm{H} ; \mathrm{R}_{2}=\mathrm{CH}_{3} ; \mathrm{R}_{3}=\right.$ furanone]; $(\mathbf{B})$ hardwickiic acid $\left[\mathrm{R}_{1}=\mathrm{COOH} ; \mathrm{R}_{2}=\mathrm{H}\right.$; $\mathrm{R}_{3}=$ furan]; (C) 15,16-epoxy-7 $\beta$-acetoxy-3,13(16),14-clerodatriene-18-oic acid $\left[\mathrm{R}_{1}=\mathrm{H} ; \mathrm{R}_{2}=\mathrm{H} ; \mathrm{R}_{3}=\right.$ furan]; (D) 7-hydroxyhardwickiic acid [ $\mathrm{R}_{1}$ $=\mathrm{OH} ; \mathrm{R}_{2}=\mathrm{CH}_{3} \mathrm{R}_{3}$ = furan]; (E) clerodane-15,18-dioic acid $\left[\mathrm{R}_{1}=\mathrm{H} ; \mathrm{R}_{2}=\mathrm{CH}_{3} ; \mathrm{R}_{3}=\mathrm{CH}\left(\mathrm{CH}_{3}\right) \mathrm{CH}_{2} \mathrm{COOCH}_{3}\right]$; (F) 3,13-clerodadiene-15-oic acid $\left[\mathrm{R}_{1}=\mathrm{COOH}\right] ;(\mathbf{G})$ colavenol $\left[\mathrm{R}_{1}=\mathrm{CH}_{2} \mathrm{OH}\right.$, trans $\left.\mathrm{C}_{1}, \mathrm{C}_{2}\right] ;(\mathbf{H})$ Cis-colavenol $\left[\mathrm{R}_{1}=\mathrm{CH}_{2} \mathrm{OH}\right.$ cis $\mathrm{C}_{1}$, $\left.\mathrm{C}_{2}\right]$; (I) 13-clerodane-15,16-olideo-18oic acid $\left[\mathrm{R}_{1}\right.$ = furanone]; (J) clerodane-15,18-dioic acid $\left[\mathrm{R}_{1}=\mathrm{CH}_{2}\left(\mathrm{CH}_{3}\right) \mathrm{CH}_{2} \mathrm{CH}_{2} \mathrm{COOH}\right] ;(\mathbf{L})$ clorechinic acid [ $\mathrm{R}_{1}=$ furan]; $(\mathbf{M})$ copaiferolic acid $\left[\mathrm{R}_{1}=\mathrm{COOH} ; \mathrm{R}_{2}=\mathrm{OH} ; \mathrm{R}_{3}=\mathrm{H} ; \mathrm{R}_{4}=\mathrm{H}\right] ;$ ( $\left.\mathbf{N}\right)$ copaiferic acid, $\left[\mathrm{R}_{1}=\mathrm{COOH} ; \mathrm{R}_{2}=\mathrm{CH}_{3} ; \mathrm{R}_{3}=\mathrm{H} ; \mathrm{R}_{4}=\mathrm{H}\right]$; (O) 8(17), 13-labdadiene-15-ol $\left[\mathrm{R}_{1}=\mathrm{CH}_{2} \mathrm{OH} ; \mathrm{R}_{2}=\mathrm{CH}_{3} ; \mathrm{R}_{3}=\mathrm{H} ; \mathrm{R}_{4}=\mathrm{H}\right] ;(\mathbf{P})$ 11-hydroxycopalic acid $\left[\mathrm{R}_{1}=\mathrm{COOH} ; \mathrm{R}_{2}=\mathrm{CH}_{3} ; \mathrm{R}_{3}=\mathrm{OH} ; \mathrm{R}_{4}=\mathrm{H}\right] ;(\mathbf{Q})$ ent-3-hydroxy-labda8(17),13-diene-15-oic acid $\left[\mathrm{R}_{1}=\mathrm{COOH} ; \mathrm{R}_{2}=\mathrm{CH}_{3} ; \mathrm{R}_{3}=\mathrm{H} ; \mathrm{R}_{4}=\mathrm{OH}\right] ;(\mathbf{R})$ ent-agatic acid $\left[\mathrm{R}_{1}=\mathrm{COOH} \mathrm{R}=\mathrm{COOH} \mathrm{R}=\mathrm{H} \mathrm{R} \mathrm{R}_{4}=\mathrm{H}\right] ;(\mathbf{S})$ copalic acid $\left[\mathrm{R}_{1}=\mathrm{COOH} ; \mathrm{R}_{2}=\mathrm{CH}_{3} ; \mathrm{R}_{3}=\mathrm{H} ; \mathrm{R}_{4}=\mathrm{H}\right] ;(\mathrm{T})$ 11-acetoxy-copalic acid $\left[\mathrm{R}_{1}=\mathrm{COOH} ; \mathrm{R}_{2}=\mathrm{CH}_{3} ; \mathrm{R}_{3}=\mathrm{CO}_{2} \mathrm{CH}_{3} ; \mathrm{R}_{4}=\mathrm{H}\right] ;(\mathbf{U})$ cativic acid; $(\mathbf{V})$ ent-16( $\beta$ )-cauranic-19-oic acid $\left[\mathrm{R}_{1}=\mathrm{CH}_{3} ; \mathrm{R}_{2}=\mathrm{H}\right] ;(\mathbf{X})$ ent-caura-16-ene-19-oic acid $\left[\mathrm{R}_{1}\right.$ and $\left.\mathrm{R}_{2}=\mathrm{CH}_{2}\right] ; \mathrm{R}_{1}$ and $\mathrm{R}_{2}$ need for two connections, one and one $\pi \sigma$.

human erythrocytes ( $\mathrm{IC}_{50}$ of 74.0 and $56.4 \mathrm{mM}$, respectively). These results indicate the cytotoxicity of kaurenoic acid [54].

\section{Copaifera's Traditional Use Validation}

The chemical composition variations of C. reticulata and the concentration of the main volatile compounds were identified by gas chromatography-mass spectrometry (GCMS). Almost 100\% were sesquiterpenes constituents with the three major compounds: $\beta$-caryophyllene, trans- $\alpha-\beta$ bergamotene, and bisabolene. However, there is a high intrapopulation variability in composition and concentration of the sesquiterpenes. However, it was unclear whether environmental, morphometric, and structural factors would affect the composition of oleoresin, although some compounds vary according to soil type, volume of extracted oleoresin, and crown surface [55].

Leishmania amazonensis is responsible for most cases of American cutaneous leishmaniasis (ACL) in the Brazilian Amazon. The ACL is a disease of worldwide occurrence, and approximately $95 \%$ of cases occur in the Americas, the Mediterranean basin, the Middle East, and Central Asia [56]. In Brazil, from 1990 to 2013, about 18,226 cases of cutaneous leishmaniasis were reported, and over $46 \%$ were recorded in the North [57].

The parasite cycle begins in the body after the blood meal, and its infectious form is the metacyclic promastigote. Few hours later, the parasite is phagocytosed and within the macrophages it differs in the amastigote form, which 
TABLE 3: Antileishmanial activity and cytotoxicity of Copaifera and terpenes present in this genre.

\begin{tabular}{|c|c|c|c|c|c|}
\hline Species & $\begin{array}{l}\text { Promastigote } \\
\left(\mathrm{IC}_{50}-\mu \mathrm{g} / \mathrm{mL}\right)\end{array}$ & $\begin{array}{c}\text { Amastigote } \\
\left(\mathrm{IC}_{50}-\mu \mathrm{g} / \mathrm{mL}\right)\end{array}$ & $\begin{array}{c}\text { Cytotoxicity } \\
\left(\mathrm{IC}_{50}-\mu \mathrm{g} / \mathrm{mL}\right) / \mathrm{IS}\end{array}$ & Chemical composition & Reference \\
\hline Copaifera reticulate & 7.88 & 0.52 & ND & & Rondon et al., 2012 [15] \\
\hline Copaifera reticulate (Pará) & $5.0 \pm 0.8$ & 20.0 & $40.0 / 8.0$ e 2.0 & $\begin{array}{c}\text { Copalic }(2.4 \%) \\
\text { kaurenoic }(3.9 \%) \text { acid }\end{array}$ & Santos et al., 2008 [10] \\
\hline Copaifera reticulata (Acre) & $22.0 \pm 0.0$ & ND & ND & $\begin{array}{c}\text { Copalic }(7.7 \%), \\
\text { kaurenoic }(7.5 \%), \\
\text { hardwickiic }(6.9 \%) \text { acid }\end{array}$ & Santos et al., 2008 [10] \\
\hline Copaifera martii & $14.0 \pm 0.9$ & ND & ND & $\begin{array}{c}\text { Kaurenoic }(7.9 \%) ; \\
\text { kovalenic }(29.0 \%) \text { acid }\end{array}$ & Santos et al., 2008 [10] \\
\hline Copaifera cearensis & $18.0 \pm 0.0$ & ND & ND & $\begin{array}{c}\text { Hardwickiic }(6.2 \%) \\
\text { copalic }(2.1 \%) \text { acid }\end{array}$ & Santos et al. 2008 [10] \\
\hline Copaifera paupera & $11.0 \pm 0.4$ & ND & ND & $\begin{array}{c}\text { Copalic }(6.1 \%) ; \\
\text { kaurenoic }(13.3 \%)\end{array}$ & Santos et al., 2008 [10] \\
\hline Copaifera langsdorffii & $20.0 \pm 0.8$ & ND & ND & $\begin{array}{c}\text { Copalic }(5.6 \%) ; \\
\text { kaurenoic }(44.3 \%) ; \\
\text { hardwickiic }(8.2 \%) \text { acid }\end{array}$ & Santos et al., 2008 [10] \\
\hline Copaifera officinalis & $20.0 \pm 0.4$ & ND & ND & $\begin{array}{c}\text { Copalic (13.9\%); } \\
\text { hardwickiic }(30.7 \%) \text { acid }\end{array}$ & Santos et al., 2008 [10] \\
\hline Copaifera multijuga & $10.0 \pm 0.8$ & ND & ND & Copalic $(6.2 \%)$ & Santos et al., 2008 [10] \\
\hline Copaifera lucens & $20.0 \pm 0.9$ & ND & ND & $\begin{array}{c}\text { Copalic }(11.1 \%) ; \\
\text { polyalthic }(69.8 \%) \text { acid }\end{array}$ & Santos et al., 2008[10] \\
\hline Copaifera paupera (Herzog) Dwyer & $>100$ & $>100$ & & & Estevez et al., 2007 [16] \\
\hline Kaurenoic acid & $28.0 \pm 0.7$ & $3.5 \pm 0.5$ & $140.0 \pm 17.0 / 40.0$ & - & dos Santos et al., 2013 [17] \\
\hline Hydroxycopalic acid & $2.5 \pm 0.4$ & $18.0 \pm 1.5$ & $40.0 \pm 2.4 / 2.2$ & - & dos Santos et al., 2013 [17] \\
\hline Polyalthic acid & $35.0 \pm 2.0$ & $15.0 \pm 1.0$ & $>500 />33.3$ & - & dos Santos et al., 2013 [17] \\
\hline Pinifolic acid & $70.0 \pm 8.0$ & $4.0 \pm 0.4$ & $>500 />125.0$ & - & dos Santos et al., 2013 [17] \\
\hline Caryophyllene oxide & & 2.9 & 85.0 & - & Soares et al., 2013 [59] \\
\hline Sesquiterpenes & & 2.3 & 92.4 & - & Soares et al., 2013 [59] \\
\hline Amphotericin B & $0.06 \pm 0.0$ & $0.23 \pm 0.0$ & ND & $\mathrm{ND}$ & dos Santos et al., 2013 [17] \\
\hline
\end{tabular}

multiplies intensely until its rupture, resulting in the release of these forms that will be phagocytosed by new macrophages in a continuous process, resulting then in hematogenous dissemination to other tissues rich in cells of the mononuclear phagocytic system, such as lymph nodes, liver, spleen, and bone marrow [58].

The evaluation of the leishmanicidal activity of copaiba was carried out mainly in strains of $L$. amazonensis. The leishmanicidal activity of $C$. reticulata in $L$. amazonensis was influenced by the chemical composition of the oil. The sample with lower content of copalic acid and kaurenoic acid is the most active one (Table 3 ). $\beta$-Caryophyllene can be considered as a marker compound of leishmanicidal activity [59], probably being in higher concentration in the samples of the oil from Para (Table 3 ).

In the amastigote forms of L. chagasi (Table 3), C. reticulata oil had higher activity, while in L. amazonensis it has shown higher activity against promastigote forms [15]. The oils obtained from Copaifera martii, Copaifera cearensis, Copaifera pauper, Copaifera langsdorffi, Copaifera multijuga, and Copaifera lucens have been shown to be active against promastigote form of $L$. amazonensis $\left(\mathrm{IC}_{50} 10-22 \mu \mathrm{g} / \mathrm{mL}\right)$. Only the oil from Copaifera pauper was not active against leishmania (Table 3) $[10,15]$.

In general, the isolated substances from the oils of copaiba showed higher activity against the amastigote forms of $L$. amazonensis, except hydroxycopalic acid (Table 3). Diterpene acids (such as pinifolic acid and kaurenoic acid) induced a considerable increase in plasma membrane permeability in the axenic amastigote forms of L. amazonensis [17]. That may explain the highest activity against this form of the parasite.

Other studies evaluated the activity of the isolated terpenes from copaiba in different forms of Trypanosoma cruzi. Amastigotes were more sensitive to the presence of different compounds from Copaifera. [60]. Similarly, the amastigote forms were more susceptible to the substances isolated from the copaiba oil (Table 3).

Exposing the parasites to the hydroxycopalic acid causes structural alterations as changes in the cell shape, flagellar membrane, and rupture of the plasmatic membrane. The loss of cellular material, abnormal condensation of chromatin, and intense exocytic activity in the region of the flagellar 
pocket is the most significant observation. The changes of the mitochondrial swelling and the appearance of concentric membranes in the interior of the organelles are found [17].

From the tested compounds, the majority did not lead to lipid peroxidation that occurs in the presence of reactive oxygen species (ROS) and may be related to the mitochondrial damage or inhibition of the detoxification system. The lipid peroxidation reaction takes place in the presence of reactive oxygen species (ROS) and may be associated with mitochondrial damage or inhibition of detoxification system [17].

When the cytotoxicity $\left(\mathrm{IC}_{50}\right)$ and the activity against promastigote and amastigote forms $\left(\mathrm{IC}_{50}\right)$ of the oil and isolated substances are related, selectivity is observed, meaning that the cytotoxic concentration $50 \%$ is higher than the inhibitory $50 \%$ (Table 3). The cytotoxicity of terpenes obtained from the copaiba oil was evaluated using a culture of mammal cells LLCMK2 and erythrocytes. Regarding the hemolytic potential, low toxicity was identified in the majority of terpenes, with $50 \%$ of hemolysis in concentrations above $400 \mu \mathrm{M}$. The pinifolic acid was the least hemolytic, causing around $8 \%$ of hemolysis in concentrations beyond $1500 \mu \mathrm{M}$. The copalic acid and the $3 \beta$-hydroxycopalic acid were the most aggressive to the erythrocytes, causing lysis in $50 \%$ in doses bellow $200 \mu \mathrm{M}[60]$.

Concerning the cytotoxicity to the nucleated cells, the terpenes were considered moderately toxic. The very low potential of $\beta$-caryophyllene against these cells, with a $\mathrm{IC}_{50}$ above $1700 \mu \mathrm{M}$, is highlighted while for the copalic acid and the $3 \beta$-hydroxycopalic acid $\mathrm{IC}_{50}$ was 39.1 and $31.2 \mu \mathrm{M}$, respectively [60]. In summary, the caryophyllene had low toxicity, and caryophyllene oxide showed activity against amastigote forms; however, studies of genotoxicity and mutagenicity and in vivo studies should be performed.

The association with $\beta$-caryophyllene and copalic acid showed a synergic effect to the activity against Trypanosoma cruzi [60]. Unfortunately, the evaluation of the synergic effect of these substances against amastigote forms of $L$. amazonensis has not yet been performed.

The acute infection of cutaneous leishmaniasis (LCL) is characterized by the presence of an inflammatory profile with an increase of T-helper 1 (Thl) response and an increase in the population of cells responsible for the production of Interleukin 12 (IL-12) and interferon gamma (IFN-y) [61]. IL-12 is a cytokine primarily released by macrophages and is known for its important role in the immunopathology of leishmania since both recruit $\mathrm{T}$ cells and natural killer (NK) cells [62]. This type of response helps reduce the parasite load resulting in the elimination of infection [63]. IL-1b is also a characteristic cytokine of an inflammatory response. This cytokine results from the activation of the caspase-1dependent inflammasome and is critical for the control of infection, as this pathway actives iNOS and consequently the nitric oxide [64]. In the case of chronic lesions, a high load is associated with the presence of cells production of IL-10, favoring the recruitment of regulatory T cells (Treg) and, as a consequence, an anergic $\mathrm{T}$ cell response (no antigen-specific response). The profile in the chronic infection is characterized by the presence of cells with the Th2 profile and an increased production of cytokines such as IL-2, IL-4, IL-6, IL-10, and transformation growth factor beta (TGF-b) leading to an anti-inflammatory response [65-70] and promoting spread of disease to other locations [70].

The immunomodulatory effect of natural products in Peripheral Blood Mononuclear Cells (PBMCs) may occur mainly through its action in the monocytes and their receptors that recognize pathogens. After cell activation, adaptor proteins can activate the transcription of the nuclear factor $\kappa \mathrm{B}$ (NF- $\kappa \mathrm{B})$, which will lead to the expression of genes of cytokines, chemokines, and antimicrobial peptides and of costimulatory molecules [71, 72]. Also, the effects of Copaifera reticulata, Copaifera duckey, and Copaifera multijuga in monocytes and the viability and the production of pro- and anti-inflammatory cytokines (TNF- $\alpha$ and IL10 , respectively) were performed. In all concentrations (5, 10 , and $20 \mu \mathrm{g} / \mathrm{mL}$ ) the oils did not affect the cell viability (>85\%) and the production of TNF- $\alpha$ induced by LPS was maintained. However, the oils reduced the production of IL10 significantly [72]. The interference in the production of cytokines suggested that the copaiba oil, probably, interferes in the chronical immune response of leishmaniasis.

Aside from the antiparasitic activity, another important question to be analyzed is whether the use of copaiba oil has a healing effect on the ulcers. The action of the copaiba oil in the cicatrization processes has been confirmed in some studies; further studies to prove with more accuracy the influence of the copaiba oil in the healing process and its toxic effects are necessary [73].

The oil resin activity of $C$. langsdorffii was evaluated in an incision wound model in rats and the contraction of the excised wounds was observed in addition to measuring the tensile strength in wound healing. Topical application of oleoresin accelerated wound contraction indicating a beneficial effect of the oil resin of $C$. langsdorffii in wound healing, thus justifying its traditional use for the treatment of wounds [9].

The cicatrization processes of cutaneous ulcers on the backs of adult male rats were compared in a histological study, where during 15 days topical applications of the copaiba oil were performed twice a day. It resulted in cicatrizations similar to the initial and final periods of the treatment and in the intermediaries of 7 days showed a complete epithelization in the cutaneous lesions, even though the copaiba oil has a slow capacity of repairing connective tissues [74].

\section{Conclusions}

Copaiba oil and its isolated terpenes have antiparasitic activity, being more promising against amastigote forms of $L$. amazonensis. This activity is probably related to the alterations in the membrane and mitochondria. This oil showed low cytotoxicity and genotoxicity. Besides that, it seems that this oil may interfere with the immune response to the infection and has ulcer healing effect. In summary, copaiba oil is promising as a leishmanicidal agent.

\section{Competing Interests}

The authors declare that there are no competing interests. 


\section{Acknowledgments}

The authors gratefully acknowledge the financial support from Conselho Nacional de Desenvolvimento Científico e Tecnológico (CNPq-Universal and Bolsa de Produtividade Tecnologica), CAPES, and PROPESP/UFPA.

\section{References}

[1] WHO, Strategic Direction for Research: Leishmaniasis. Special Programme for Research and Training in Tropical Diseases, World Health Organization, Tropical Diseases Research (TDR), Geneva, Switzerland, 2002.

[2] WHO, Leishmaniasis-A Brief History of the Disease, World Health Organization, Geneva, Switzerland, 2014, http://apps.who .int/iris/bitstream/10665/111008/1/WHO_DCO_WHD_2014.1_eng .pdf.

[3] C. A. Paraguassu-Chaves, Geografia Médica ou da Saúde (Espaço e doença na Amazônia Ocidental), Edufro, 1st edition, 2001.

[4] B. Gontijo and M. L. R. Carvalho, "American cutaneous leishmaniasis," Journal of the Brazilian Society of Tropical Medicine, vol. 36, no. 1, pp. 71-80, 2003.

[5] Brazil, Ministry of Health, Department of Health, and Secretary of Surveillance in Health, Manual of Surveillance of American Tegumentary Leishmaniasis, House of the Ministry of Health, Brasília, Brazil, 2th edition, 2010.

[6] A. G. L. Oliveira, Influência do Estado Nutricional na Evolução Clínica e Terapêutica de Adultos e Idosos com Leishmaniose Tegumentar Americana [M.S. dissertation], Fundação Oswaldo Cruz, Rio de Janeiro, Brazil, 2013.

[7] A. C. B. Carvalho and D. Silveira, "Drogas vegetais: uma antiga nova forma de utilização de plantas medicinais," Brasília Médica, vol. 48, no. 2, pp. 219-237, 2010.

[8] D. M. Silva and K. R. Mocelin, "O cuidado de enfermagem ao cliente portador de feridas sob a ótica do cuidado transcultural," Nursing, vol. 9, no. 105, pp. 81-88, 2007.

[9] L. A. F. Paiva, K. M. De Alencar Cunha, F. A. Santos, N. V. Gramosa, E. R. Silveira, and V. S. N. Rao, "Investigation on the wound healing activity of oleo-resin from Copaifera langsdorffi in rats," Phytotherapy Research, vol. 16, no. 8, pp. 737-739, 2002.

[10] A. O. Santos, T. Ueda-Nakamura, B. P. Dias Filho, V. F. Veiga Jr., A. C. Pinto, and C. V. Nakamura, "Effect of Brazilian copaiba oils on Leishmania amazonensis," Journal of Ethnopharmacology, vol. 120, no. 2, pp. 204-208, 2008.

[11] L. N. Pinto, Plantas medicinais utilizadas por comunidades do município de Igarapé-Miri, Pará: etnofarmácia do município de Igarapé-Miri-PA [M.S. dissertation], Universidade Federal do Pará, Belém, Brazil, 2008.

[12] Center of the Workers of the Amazon (CTA), Processing Booklet for Non-Timber Products: Medicinal Plants of the Forest, Poronga Publishing House, Rio Branco, Brazil, 1996.

[13] V. F. Veiga Jr. and A. C. Pinto, "O Gênero Copaifera L.," Química Nova, vol. 25, no. 2, pp. 273-286, 2002.

[14] V. Cascon and B. Gilbert, "Characterization of the chemical composition of oleoresins of Copaifera guianensis Desf., Copaifera duckei Dwyer and Copaifera multijuga Hayne," Phytochemistry, vol. 55, no. 7, pp. 773-778, 2000.

[15] F. C. M. Rondon, C. M. L. Bevilaqua, M. P. Accioly et al., "In vitro efficacy of Coriandrum sativum, Lippia sidoides and Copaifera reticulata against Leishmania chagasi," Brazilian Journal of Veterinary Parasitology, vol. 21, no. 3, pp. 185-191, 2012.
[16] Y. Estevez, D. Castillo, M. T. Pisango et al., "Evaluation of the leishmanicidal activity of plants used by Peruvian Chayahuita ethnic group," Journal of Ethnopharmacology, vol. 114, no. 2, pp. 254-259, 2007.

[17] A. O. dos Santos, E. Izumi, T. Ueda-Nakamura, B. P. Dias-Filho, V. F. da Veiga-Júnior, and C. Vataru Nakamura, "Antileishmanial activity of diterpene acids in copaiba oil," Memorias do Instituto Oswaldo Cruz, vol. 108, no. 1, pp. 59-64, 2013.

[18] V. F. Veiga Jr., L. Zunino, M. L. Patitucci, A. C. Pinto, and J. B. Calixto, "The inhibition of paw oedema formation caused by the oil of Copaifera multijuga Hayne and its fractions," Journal of Pharmacy and Pharmacology, vol. 58, no. 10, pp. 1405-1410, 2006.

[19] F. D. F. Fernandes and E. D. P. S. Freitas, "Acaricidal activity of an oleoresinous extract from Copaifera reticulata (Leguminosae: Caesalpinioideae) against larvae of the southern cattle tick, Rhipicephalus (Boophilus) microplus (Acari: Ixodidae)," Veterinary Parasitology, vol. 147, no. 1-2, pp. 150-154, 2007.

[20] V. F. Veiga Jr., M. A. Andrade Jr., I. D. K. Ferraz, H. B. Christo, and A. C. Pinto, "Constituents from Copaifera officinalis L. seeds," Acta Amazonica, vol. 37, no. 1, pp. 123-126, 2007.

[21] J. F. Milani, J. F. Rocha, and S. P. Teixeira, "Oleoresin glands in copaiba (Copaifera trapezifolia Hayne: Leguminosae), a Brazilian rainforest tree," Biblioteca Digital da Produção IntelectualBDPI Trees, vol. 26, no. 3, pp. 769-775, 2012.

[22] G. Wood, C. H. LaWall, H. W. Youngken, A. Osol, I. Griffith, and L. Gershenfeld, The Dispensatory of the United States of America, J. B. Lippincott \& Co, Philadelphia, Pa, USA, 22th edition, 1940.

[23] W. Mors and C. T. Rizzini, Useful Plants of Brazil, Holden-Day, San Francisco, Calif, USA, 1st edition, 1966.

[24] F. Pieri, M. Mussi, and M. Moreira, "Óleo de copaíba (Copaifera sp.): histórico, extração, aplicações industriais e propriedades medicinais," Revista Brasileira de Plantas Medicinais, vol. 11, no. 4, pp. 465-472, 2009.

[25] W. F. Braga, C. M. Rezende, O. A. C. Antunes, and A. C. Pinto, "Terpenoids from Copaiba cearensis," Phytochemistry, vol. 49, no. 1, pp. 263-264, 1998.

[26] H. D. S. Falcão, I. O. Lima, V. L. Santos et al., "Review of the plants with anti-inflammatory activity studied in Brazil," Brazilian Journal of Pharmacognosy, vol. 15, no. 4, pp. 381-391, 2005.

[27] V. Salvador, História do Brasil: 1500-1627, Melhoramentos, 6th edition, 1975.

[28] J. A. Wenninger, R. L. Yates, and M. Dolinsky, "Sesquiterpene hydrocarbons of commercial copahyba balsam and American Cedarwood oils," Journal of the AOAC International, vol. 50, no. 6, pp. 1304-1313, 1967.

[29] M. Calvin, "Hydrocarbons from plants: analytical methods and observations," Naturwissenschaften, vol. 67, no. 11, pp. 525-533, 1980.

[30] A. A. Craveiro, A. G. Fernandes, C. H. S. Andrade, F. J. D. A. Matos, J. W. Alencar, and M. I. L. Machado, Óleos Essenciais de Plantas do Nordeste, UFC, Fortaleza, Brazil, 1st edition, 1981.

[31] M. Ferrari, U. M. Pagnoni, F. Pelizzoni, V. Lukeš, and G. Ferrari, “Terpenoids from Copaifera langsdorfii," Phytochemistry, vol. 10, no. 4, pp. 905-907, 1971.

[32] P. Morin, H. Pichard, H. Pichard, M. Caude, and R. Rosset, "Supercritical fluid chromatography of sesquiterpene hydrocarbons on silica packed columns with on-line Fourier transform infrared detection," Journal of Chromatography A, vol. 464, no. C, pp. 125-137, 1991. 
[33] E. Stashenko, H. Wiame, S. Dassy, J. R. Martinez, and T. Shibamoto, "Catalytic transformation of copaiba (Copaifera officinalis) oil over zeolite ZSM-5," Journal of High Resolution Chromatography, vol. 18, no. 1, pp. 54-58, 1995.

[34] V. F. Veiga Jr., Controle de qualidade de óleos de copaíba por cromatografia gasosa de alta resolução [M.S. dissertation], Universidade Federal do Rio de Janeiro, Rio de Janeiro, Brazil, 1997.

[35] F. Delle Monache, F. Ferrari, I. L. D’Albuquerque, and G. B. Marini Bettolo, "Stereochemistry of proanthrocyanidine from Ouratea Sp. (Ochnaceae)," Il Farmaco; edizione scientifica, vol. 25, no. 2, pp. 96-105, 1970.

[36] R. A. Spanevello and A. J. Vila, "7- $\alpha$-Acetoxyhardwickiic acid: a furanoid clerodane,” Phytochemistry, vol. 35, no. 2, pp. 537-538, 1994.

[37] A. Ohsaki, L. T. Yan, S. Ito, H. Edatsugi, D. Iwata, and Y. Komoda, "The isolation and in vivo potent antitumor activity of clerodane diterpenoid from the oleoresin of the Brazilian medicinal plant, Copaifera langsdorfi desfon.", Bioorganic and Medicinal Chemistry Letters, vol. 4, no. 24, pp. 2889-2892, 1994.

[38] H. Monti, N. Tiliacos, and R. Faure, "Two diterpenoids from copaiba oil," Phytochemistry, vol. 42, no. 6, pp. 1653-1656, 1996.

[39] A. C. Pinto, O. A. C. Antunes, C. M. Rezende, and C. R. D. Correia, "Separation of acidic components of Vellozia flavicans by silica gel/potassium hydroxide chromatography," Phytochemical Analysis, vol. 8, no. 1, pp. 14-17, 1997.

[40] A. C. Pinto, W. F. Braga, C. M. Rezende et al., "Separation of acid diterpenes of Copaifera cearensis Huber ex Ducke by flash chromatography using potassium hydroxide impregnated silica gel," Journal of the Brazilian Chemical Society, vol. 11, no. 4, pp. 355-360, 2000.

[41] J. R. Mahajan and G. A. L. Ferreira, "New diterpenoids from copaiba oil," Annals of the Brazilian Academy of Sciences, vol. 43, pp. 611-613, 1971.

[42] A. C. Basile, J. A. A. Sertié, P. C. D. Freitas, and A. C. Zanini, "Anti-inflammatory activity of oleoresin from Brazilian copaifera," Journal of Ethnopharmacology, vol. 22, no. 1, pp. 101109, 1988.

[43] R. M. Fernandes, N. A. Pereira, and L. G. Paulo, "Antiinflammatory activity of copaiba balsam (Copaifera cearenses, Huber)," Brazilian Journal of Pharmacy, vol. 73, pp. 53-56, 1992.

[44] M. A. M. Maciel, A. C. Pinto, and V. F. Veiga Jr., "Medicinal plants: the need for multidisciplinary scientific studies," Química Nova, vol. 25, no. 3, pp. 429-438, 2002.

[45] E. Estrella and M. Picasso Botto, Medicinal plants form the Amazon Region: reality and perspective [Monograph], Tratado de Cooperación Amazonica, Secretaria Pro Tempore, Lima, Peru, 1995.

[46] J. Revilla, Plantas da Amazônia: Oportunidades Econômicas e Sustentáveis, SEBRAE: INPA, 3rd edition, 2001.

[47] M. N. S. Rios and F. Pastore Junior, Plantas da Amazônia: 450 Espécies de Uso Geral, A Biblioteca Central da Universidade de Brasília, Brasilia, Brazil, 2011, http://leunb.bce.unb.br/handle/ 123456789/19.

[48] U. D. Oliveira, J. F. Marins, and S. J. R. Chiuchetta, "Avaliação do ciclo celular de Aspergillus nidulans exposto ao extrato da planta Copaifera officinalis L," SaBios-Revista Saúde e Biologia, vol. 1, no. 2, pp. 42-47, 2005.

[49] V. F. Veiga Junior, A. C. Pinto, and M. A. M. Maciel, "Plantas medicinais: cura segura?” Química Nova, vol. 28, no. 3, pp. 519$528,2005$.
[50] A. Ribeiro, Avaliação do potencial irritativo do óleo-resina de copaíba (substituto do eugenol) na fase exsudativa do processo inflamatório [M.S. thesis], Universidade de São Paulo, Bauru, Brazil, 1989.

[51] C. G. Sachetti, R. R. de Carvalho, F. J. R. Paumgartten, O. A. Lameira, and E. D. Caldas, "Developmental toxicity of copaiba tree (Copaifera reticulata Ducke, Fabaceae) oleoresin in rat," Food and Chemical Toxicology, vol. 49, no. 5, pp. 1080-1085, 2011.

[52] J. M. Alves, C. C. Munari, M. de Azevedo Bentes Monteiro Neto et al., "In vivo protective effect of Copaifera langsdorffii hydroalcoholic extract on micronuclei induction by doxorubicin," Journal of Applied Toxicology, vol. 33, no. 8, pp. 854-860, 2013.

[53] Â. G. Batista, A. S. Ferrari, D. C. Da Cunha et al., "Polyphenols, antioxidants, and antimutagenic effects of Copaifera langsdorffii fruit," Food Chemistry, vol. 197, pp. 1153-1159, 2016.

[54] L. V. Costa-Lotufo, G. M. A. Cunha, P. A. M. Farias et al., "The cytotoxic and embryotoxic effects of kaurenoic acid, a diterpene isolated from Copaifera langsdorffii oleo-resin," Toxicon, vol. 40, no. 8, pp. 1231-1234, 2002.

[55] C. Herrero-Jáuregui, M. A. Casado, M. Das Graças Bichara Zoghbi, and R. Célia Martins-Da-Silva, "Chemical variability of Copaifera reticulata ducke oleoresin," Chemistry \& Biodiversity, vol. 8, no. 4, pp. 674-685, 2011.

[56] WHO, Leishmaniasis, World Health Organization, Geneva, Switzerland, 2016, http://www.who.int/mediacentre/factsheets/ fs375/en/.

[57] Brazil, Casos de Leishmaniose Tegumentar Americana. Brasil, grandes regiões e Unidades Federadas. 1990 a 2013, Brasília, Brazil, 2013, http://u.saude.gov.br/images/pdf/2014/setembro/ 09/LT-Casos.pdf.

[58] Brazil; Ministry of Health; Department of Health and Secretary of Surveillance in Health, Surveillance Manual and Control of Visceral Leishmaniasis, House of the Ministry of Health, Brasília, Brazil, 1st edition, 2003.

[59] D. C. Soares, N. A. Portella, M. F. Ramos, A. C. Siani, and E. M. Saraiva, "Trans- $\beta$-caryophyllene: an effective antileishmanial compound found in commercial copaiba oil (Copaifera spp.)," Evidence-Based Complementary and Alternative Medicine, vol. 2013, Article ID 761323, 13 pages, 2013.

[60] E. Izumi, T. Ueda-Nakamura, V. F. Veiga, A. C. Pinto, and C. V. Nakamura, "Terpenes from copaifera demonstrated in vitro antiparasitic and synergic activity," Journal of Medicinal Chemistry, vol. 55, no. 7, pp. 2994-3001, 2012.

[61] G.-J. Feng, H. S. Goodridge, M. M. Harnett et al., "Extracellular signal-related kinase (ERK) and p38 mitogen-activated protein (MAP) kinases differentially regulate the lipopolysaccharidemediated induction of inducible nitric oxide synthase and IL-12 in macrophages: leishmania phosphoglycans subvert macrophage IL-12 production by targeting ERK MAP kinase," The Journal of Immunology, vol. 163, no. 12, pp. 6403-6412, 1999.

[62] R. L. Coffman, R. Correa-Oliviera, and S. Mocci, "Reversal of polarized T helper 1 and T helper 2 cell populations in murine leishmaniasis," Ciba Foundation symposium, vol. 195, pp. 202533, 1995.

[63] S. Nylén and L. Eidsmo, "Tissue damage and immunity in cutaneous leishmaniasis," Parasite Immunology, vol. 34, no. 12, pp. 551-561, 2012.

[64] D. S. Lima-Junior, D. L. Costa, V. Carregaro et al., "Inflammasome-derived IL- $1 \beta$ production induces nitric oxide-mediated resistance to Leishmania," Nature Medicine, vol. 19, no. 7, pp. 909-915, 2013. 
[65] J. Convit, M. Ulrich, C. T. Fernández et al., "The clinical and immunological spectrum of American cutaneous leishmaniasis," Transactions of the Royal Society of Tropical Medicine and Hygiene, vol. 87, no. 4, pp. 444-448, 1993.

[66] A. P. Campanelli, C. I. Brodskyn, V. Boaventura et al., "Chemokines and chemokine receptors coordinate the inflammatory immune response in human cutaneous leishmaniasis," Human Immunology, vol. 71, no. 12, pp. 1220-1227, 2010.

[67] N. L. Díaz, O. Zerpa, and F. J. Tapia, "Chemokines and chemokine receptors expression in the lesions of patients with American cutaneous leishmaniasis," Memórias do Instituto Oswaldo Cruz, vol. 108, no. 4, pp. 446-452, 2013.

[68] G. Valencia-Pacheco, E. N. Loría-Cervera, E. I. Sosa-Bibiano et al., "In situ cytokines (IL-4, IL-10, IL-12, IFN- $\gamma$ ) and chemokines (MCP-1, MIP-1 $\alpha$ ) gene expression in human Leishmania (Leishmania) mexicana infection," Cytokine, vol. 69, no. 1, pp. 56-61, 2014.

[69] J. França-Costa, J. Van Weyenbergh, V. S. Boaventura et al., "Arginase I, polyamine, and prostaglandin E2 pathways suppress the inflammatory response and contribute to diffuse cutaneous leishmaniasis," Journal of Infectious Diseases, vol. 211, no. 3, pp. 426-435, 2015.

[70] L. B. Samper, Envolvimento de CD200 na infectividade de isolados de Leishmania (leishmanial) amazonensis associados a leishmaniose cutânea localizada e leishmaniose cutânea difusa [M.S. thesis], Universidade de São Paulo, São Paulo, Brazil, 2015.

[71] G. M. Barton and R. Medzhitov, "Toll-like receptor signaling pathways," Science, vol. 300, no. 5625, pp. 1524-1525, 2003.

[72] K. B. Santiago, B. J. Conti, B. F. Murbach Teles Andrade et al., "Immunomodulatory action of Copaifera spp oleoresins on cytokine production by human monocytes," Biomedicine and Pharmacotherapy, vol. 70, pp. 12-18, 2015.

[73] L. V. Montes, L. P. Broseghini, F. S. Andreatta, M. E. S. Sant'Anna, V. M. Neves, and A. G. Silva, "Evidences for the use of copaiba oil-resin in wound healing-a systematic review," Natureza on Line, vol. 7, no. 2, pp. 61-67, 2009.

[74] A. T. Cavalcanti Neto, T. E. P. Arruda, T. T. P. Arruda, S. L. S. Pereira, and E. Turatti, "Comparative evaluation between copaiba oil-resin and chlorhexidine digluconate on wound healing. Histological study in rats," Revista de Odontologia da UNESP, vol. 34, no. 2, pp. 107-112, 2005. 


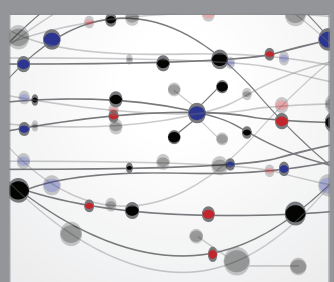

The Scientific World Journal
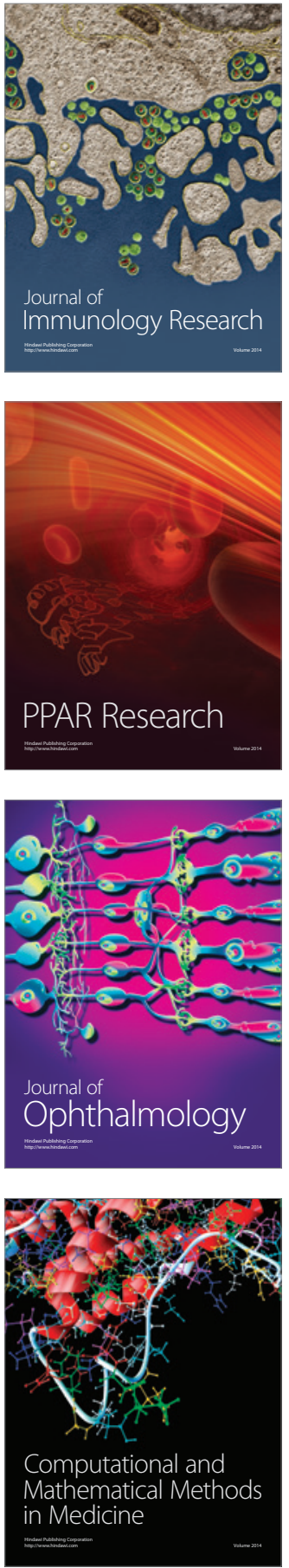

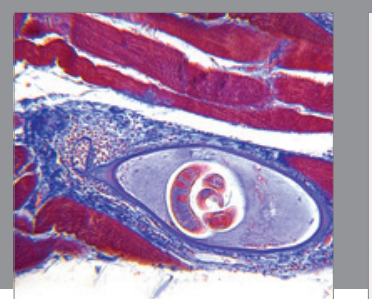

Gastroenterology Research and Practice
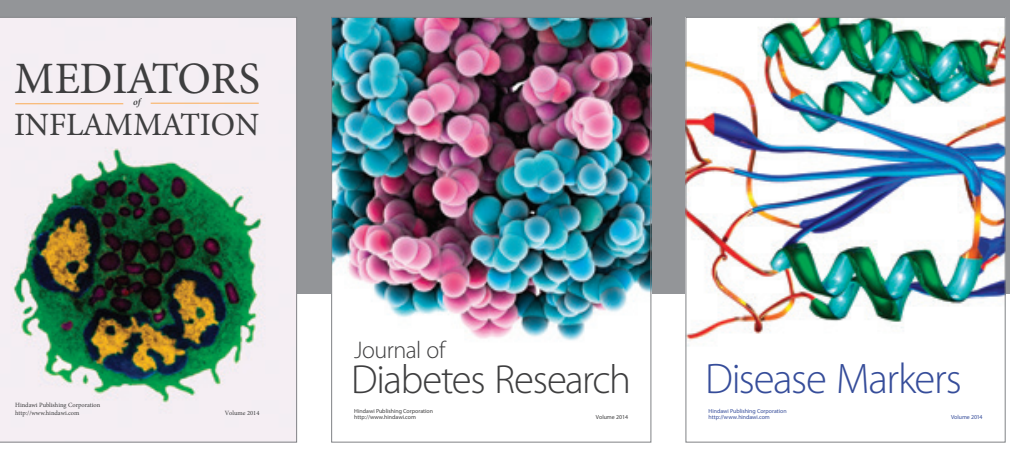

Disease Markers

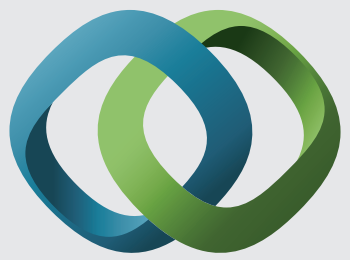

\section{Hindawi}

Submit your manuscripts at

https://www.hindawi.com
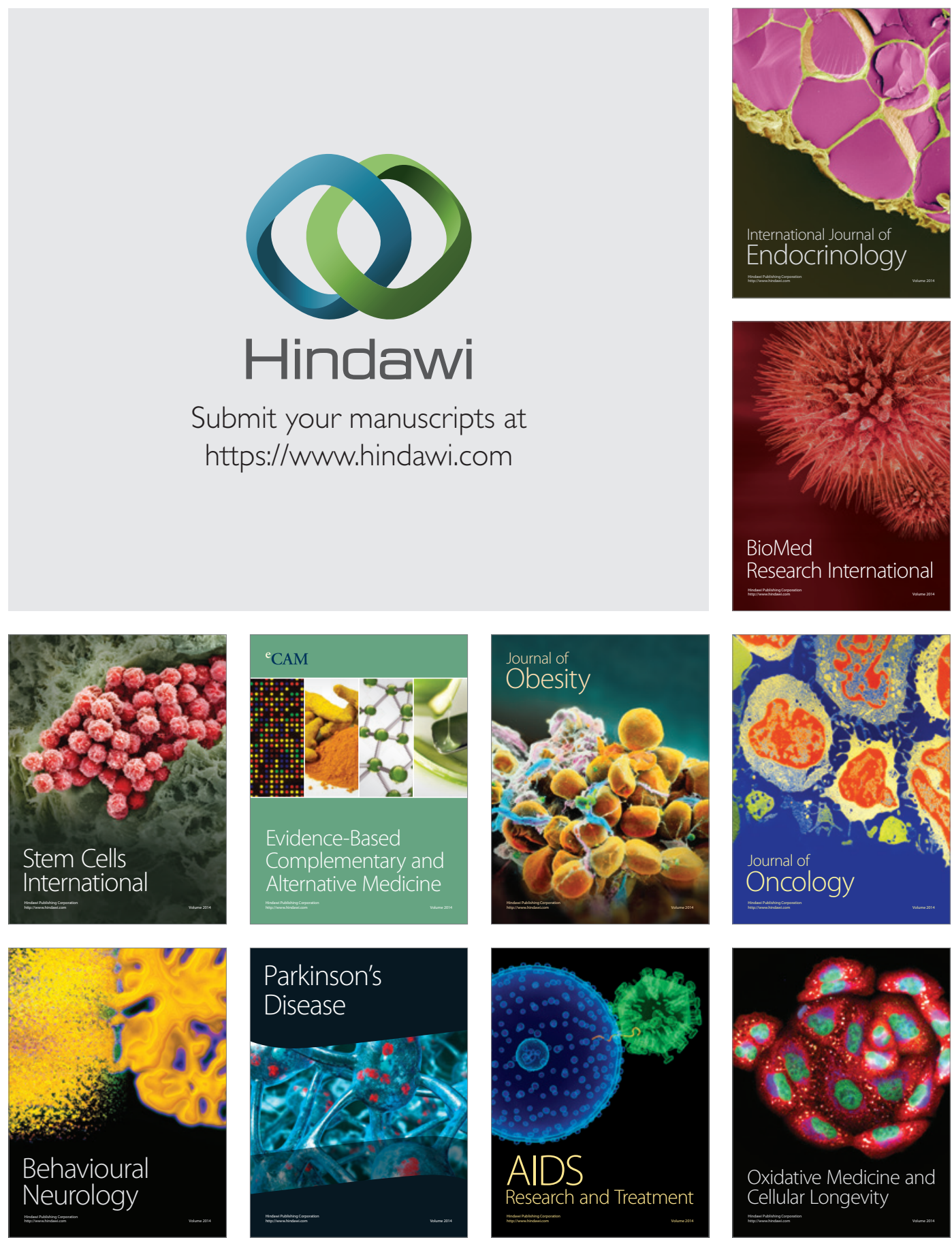